\title{
Identification and quantification of major malonyl ginsenosides isolated from Panax ginseng C.A. Meyer
}

\author{
Woo Cheol Shin ${ }^{1,2} \cdot$ Jiyun Jung ${ }^{3}$ Hyeon Seon $\mathrm{Na}^{1,2} \cdot$ Jeon Hwang $\mathrm{Bo}^{4}$. \\ Hyoung-Geun Kim ${ }^{4} \cdot$ Dahye Yoon $^{1} \cdot$ Bo-Ram Choi $^{1,4}$ - Young-Seob Lee ${ }^{1}$. \\ Geum-Soog Kim ${ }^{1} \cdot$ Nam-In Baek ${ }^{4}$ Yi Lee $^{2} \cdot$ Dae Young Lee $^{1}$ (iD
}

\section{인삼(Panax ginseng C.A. Meyer)로부터 Malonyl ginsenoside의 분리 및 정량분석}

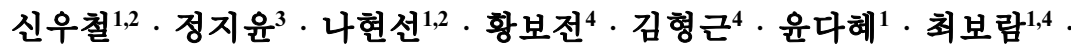 \\ 이영섭 ${ }^{1} \cdot$ 김금숙 $^{1}$. 백남인 ${ }^{4}$. 이 이 ${ }^{2}$. 이대영 ${ }^{1}$
}

Received: 14 October 2019 / Accepted: 25 October 2019 / Published Online: 31 December 2019

(C) The Korean Society for Applied Biological Chemistry 2019

\begin{abstract}
The root of Panax ginseng C.A. Meyer were extracted with $70 \%$ aqueous $\mathrm{EtOH}$ and the concentrates were partitioned into $\mathrm{MeOH}$ and $\mathrm{H}_{2} \mathrm{O}$ fractions using Diaion HP-20. The repeated $\mathrm{SiO}_{2}$ or octadecyl $\mathrm{SiO}_{2}$ column, and MPLC for the MeOH fraction led to isolation of four malonyl ginsenosides. The chemical structures of these compounds were determined as malonyl ginsenoside $\mathrm{Rd}$ (1) malonyl ginsenoside Rc (2) malonyl ginsenoside Rb2 (3) malonyl ginsenoside Rb1 (4) based on spectroscopic analyses including Nuclear magnetic resonance and HR-TOF/MS. The contents of malonyl ginsenoside Rbl was
\end{abstract}

Dae Young Lee $(\bowtie)$

E-mail: dylee0809@gmail.com

${ }^{1}$ Department of Herbal Crop Research, National Institute of Horticultura and Herbal Science, RDA, Eumseong 27709, Republic of Korea

${ }^{2}$ Department of Industrial Plant Science and Technology, Chungbuk National University, Cheongju 28644, Republic of Korea

${ }^{3}$ Punggi Ginseng Research Institute, GBARES, Youngju 36052, Republic of Korea

${ }^{4}$ Graduate School of Biotechnology and Department of Oriental Medicine Biotechnology, Kyung Hee University, Yongin 17104, Republic of Korea

This is an Open Access article distributed under the terms of the Creative Commons Attribution Non-Commercial License (http://creativecommons. org/licenses/by-nc/3.0/) which permits unrestricted non-commercial use, distribution, and reproduction in any medium, provided the original work is properly cited. highist as $5.44 \mathrm{mg} / \mathrm{g}$ of five years of ginseng. And malonyl ginsenoside Rd was lowest as $0.11 \mathrm{mg} / \mathrm{g}$ of six years of ginseng. Additionally, the malonyl ginsenoside $\mathrm{Rd}$ exhibited hepatoprotective effect against ethanol-induced hepatotoxicity in HepG2 cell line.

Keywords Hepatoprotective activity - Malonyl ginsenoside · Nuclear magnetic resonance $\cdot$ Panax ginseng $\cdot$ Quantification

\section{서 론}

고려인삼(Panax ginseng C.A. Meyer)은 두릅나무과에(Araliaceae) 속하는 다년생 초본이며[1], 한방에서는 강장제, 피로회복제, 육 체 활력을 유지하는데 도움을 주는 약용작물로서 한국과 중국 에서 오랫동안 사용되어 왔다[2]. 보고된 활성으로는 면역, 항 암, 항고혈압, 항산화, 항당뇨 등에 대한 효능이 보고되어 있다 [3]. 고려인삼의 ginsenosides는 그 화학구조에 따라 크게 protopanaxadiol (PPD), protopanaxtriol 계열 등으로 분류하며, 지금까지 수십 여종이 분리 보고되어 있다[4]. 그 중 malonyl ginsenoside는 aglycone에 malonyl acid 한 분자가 ester결합 된 구조로 산성 사포닌의 일종이다[5]. 다른 ginsenoside 보다 수용 성이 강하며, malonyl 기가 불안정하여 열이나 알카리에 의해 쉽게 떨어진다고 보고되어 있다[6].

인삼 뿌리로부터 malonyl ginsenoside-Rb1, -Rb2, -Rc, - Rd 
가 최초로 분리 및 보고된 이후, 뿌리뿐만 아니라 인삼 꽃봉오 리에서 신규 malonyl ginsenoside가 분리 보고되었다[7,8]. Malonyl ginsenoside는 주로 수삼과 백삼에 많이 존재한다고 알 려졌으나 추출 용매 및 방법에 따라 그 함량 변화가 일어나기 때문에 총 ginsenoside 함량을 분석하거나, 인삼의 품질 검사를 위한 항목에서 제외되었다[7,9]. 최근 연구에서는 수삼의 malonyl ginsenoside -Rb1, -Rb2, -Rc, -Rd의 함량이 ginsenoside-Rb1, $-\mathrm{Rb} 2,-\mathrm{Rc},-\mathrm{Rd}$ 의 함량의 2 배 이상이며, 총 ginsenoside 함량의 $45 \%$ 를 함유하고[10], 백삼에서는 앞서 언급된 4종을 포함한 총 10 종의 malonyl ginsenoside 함량이 총 ginsenoside 함량의 $36 \%$ 를 함유하고 있다고 보고되어 있다[11]. 또한, Kitagawa 등 은 백삼보다 홍삼에서 ginsenoside $\mathrm{Rb} 1, \mathrm{Rb} 2, \mathrm{Rc}$ 및 $\mathrm{Rd}$ 의 함 량이 증가된다고 최초 보고하였으며[7], 이러한 결과는 malonyl 기가 수삼(백삼)을 증숙 하는 과정에서 가열처리에 의해 탈 malonyl화 되어 각각 ginsenoside $\mathrm{Rb} 1, \mathrm{Rb} 2, \mathrm{Rc}$ 및 $\mathrm{Rd}$ 로 전 환되었기 때문이다. 이처럼 백삼과 수삼에서 높은 비율을 차지 하는데도 불구하고, 아직까지 함량에 대한 기준이 제시되지 않 고 있다.

본 연구에서는 고려 인삼(백삼)으로부터 저온 추출 등을 이 용하여 malonyl ginsenoside를 안정하게 분리하였으며 순도 높 은 표준품을 확보하고, 최신 $\mathrm{NMR}$ data $(600 \mathrm{MHz})$ 값 및 질량 값을 이용하여 구조 동정을 하였다. 또한 홍삼으로 많이 사용 되고 있는 5 년근 및 6 년근의 인삼(동체)에 함유 되어있는 4 종 의 malonyl ginsenoside 함량을 분석하였으며 HepG2로 유발된 간암세포로부터 malonyl ginsenoside의 간 기능 개선의 활성여 부를 확인하고자 연구를 진행하였다.

\section{재료 및 방법}

\section{실험재료}

실험에서 사용된 원료인 수삼 시료는 세종시의 인삼재배 농가 포장을 선정하여 채굴한 인삼을 시료로 사용하였다. 백삼제조는 우신산업(주) 관행제조 공정에 준하여 제조되었으며[12], 수분함 량이 $15 \%$ 이하인 백삼을 선별하여 사용하였다. 정량분석에 사 용된 5년 및 6 년근의 수삼은 풍기인삼시험장의 시험포장에서 재배된 것을 제공받아 분석했다. 표본시료 NIHHS 201711는 국 립원예특작과학원 인삼특작부에 보관되어 있다.

\section{시약 및 기기}

Column chromatography (c. c.)용 silica gel $\left(\mathrm{SiO}_{2}\right)$ resin은 Kiesel gel 60 (Merck, Darmstadt, Germany)을 octadecyl $\mathrm{SiO}_{2}$ (ODS) 은 Lichroprep RP-18 (40-60 $\mu \mathrm{M}$, Merck)을 사용하였다. Thin layer chromatography (TLC)는 Kiesel gel 60 F254와 RP-18 $\mathrm{F} 254 \mathrm{~s}$ (Merck)을 사용하였다. 물질 정제에 사용된 기기는 $\mathrm{YMC}$ LC-Forte/R (YMC Co., LTD. Kyoto, Japan)를 사용하였다. Nuclear magnetic resonance (NMR) 스펙트럼은 $600 \mathrm{MHz}$ FTNMR spectrometer (Varian Inova AS-600, Palo Alto, CA, USA)를 사용하였고, infrared (IR) spectrum은 Perkin model 599B (Perkin-Elmer, Waltham, MA, USA)로 측정하였다. 고분 해능 질량값의 측정은 UPLC (Waters ACQUITY I-Class, Waters Corp. Milford, MA, USA)가 부착된 Q-TOF MS (Waters
Xevo G2-S QTOF MS, Waters Corp.)를 사용하였으며, 정량분 석에는 3200 QTRAP mass spectrometer (AB SCIEX, Framingham, MA, USA)를 사용하였다. 분석을 위한 증류수, methanol $(\mathrm{MeOH})$ 및 acetonitrile $(\mathrm{MeCN})$ 은 HPLC급(Fisher Scientific, Waltham, MA, USA)을 사용하였으며, 분석 용매에 첨가한 formic $\mathrm{acid}$ 는 $99.0 \%$ 의 $\mathrm{Optima}^{\mathrm{TM}} \mathrm{LC} / \mathrm{MS}$ (Fisher Scientific) 급을 사용하였다. 그 외의 시약 및 용매는 모두 일 급 이상의 시약을 구입하여 사용하였다. 세포 생존율 시험에서 사용한 DMEM 배지는 Lonza (Basel, Switzerland)에서 구입하 였고, fetal Bovine Serum (FBS)은 Hyclone (Logan, UT, USA)에서 구입하였다. MTT (3-[4,5-dimetylthiazol-2-yl]-2,5diphenyltetrazolium bromide)와 DMSO는 Sigma-Aldrich (St. Louis, MO, USA)에서 구입하여 사용하였다.

\section{추출 및 분리}

Malonyl ginsenoside의 수율을 최대화하기 위하여 백삼 $3 \mathrm{~kg}$ 를 $70 \% \mathrm{EtOH}$ 수용액에 24 시간 담가서 $10^{\circ} \mathrm{C}$ 이하의 저온 추출을 2 회 반복하였다. 얻어진 여액을 합쳐 저온 $\left(30^{\circ} \mathrm{C}\right)$ 에서 감압 농 축하여 $\mathrm{EtOH}$ 추출물 $(330 \mathrm{~g})$ 을 얻었다. 얻어진 $\mathrm{EtOH}$ 추출물을 Diaion HP-20 c.c. $\left(\varphi \quad 10 \times 40 \mathrm{~cm}, \mathrm{H}_{2} \mathrm{O} \rightarrow \mathrm{MeOH}\right)$ 를 실시하여 각 $500 \mathrm{~mL}$ 식 분취하였다. 각 분취액을 $\mathrm{SiO}_{2} \mathrm{TLC}$ 로 당이 제거 되었는지를 확인하고, 비슷한 여액을 합친 후, 감압 농축하여 분획물 $(40 \mathrm{~g})$ 을 얻었다. 분획 $(20 \mathrm{~g})$ 에 대하여 $\mathrm{SiO}_{2}$ c.c. (Ф 6.0× $22.0 \mathrm{~cm}, \mathrm{CHCl}_{3}-\mathrm{MeOH}-\mathrm{H}_{2} \mathrm{O}=15: 3: 1 \rightarrow 7: 3: 1 \rightarrow 6: 4: 1$, 총 $30 \mathrm{~L}$ 사용)를 실시하여 총 17 개의 분획물(PG-1-PG-17)을 얻었다. 그 중 PG-4-7 분획, PG-9 분획, PG-10 분획 및 PG-11-14 분획 에 대하여 중압분취장비(Medium Pressure Liquid Chromatography, YMC LC-Forte/R)를 이용하여 분리를 진행하였다. PG-4-7분획 에 대하여 MPLC를 진행하였다. 이때 사용된 컬럼은 YMCpack pro $\mathrm{C} 18(20 \mathrm{~mm} \times 250 \mathrm{~mm}, 10 \mu \mathrm{m})$ 를 사용하였으며 이동 상의 용매는 $\mathrm{A}\left(\mathrm{H}_{2} \mathrm{O}\right): \mathrm{B}(\mathrm{MeCN})$ 를 사용하였고, $\mathrm{A}$ : B (85:15, 0-2 min), A : B (80:20, 2-4 min), A : B (80:20, 4-10 min), $\mathrm{A}: \mathrm{B}(70: 30,10-25 \mathrm{~min}), \mathrm{A}: \mathrm{B}(40: 60,25-45 \mathrm{~min}), \mathrm{A}: \mathrm{B}(10: 90$ $45-52 \mathrm{~min}), \mathrm{A}: \mathrm{B}(10: 90,60 \mathrm{~min})$ 의 조건에서 $5 \mathrm{~mL} / \mathrm{min}$ 의 유 속으로 $203 \mathrm{~nm}$ 파장에서 분리를 하였으며 총 4개의 분획물을 얻었다. 그중 PG-4-7-1 분획 $(310 \mathrm{mg})$ 에 대하여 직경 $\Phi 10 \mathrm{~mm}$ 의 분취컬럼(YMC-pack pro $\mathrm{C} 18,10 \mathrm{~mm} \times 250 \mathrm{~mm}, 5 \mu \mathrm{m})$ 을 사용하였으며 이동상의 기울기 조건은 $\mathrm{A}: \mathrm{B}$ (90:10, 0-0.15 $\min ), \mathrm{A}: \mathrm{B}(65: 35,0.15-5 \mathrm{~min}), \mathrm{A}: \mathrm{B}(50: 50,5-25 \mathrm{~min}), \mathrm{A}: \mathrm{B}$ $(0: 100,25-30 \mathrm{~min})$ 의 조건에서 $2 \mathrm{~mL} / \mathrm{min}$ 의 유속으로 $203 \mathrm{~nm}$ 파장에서 분리를 하였다. 총 7개의 분획(PG-4-7-1-1 PG-4-7-17)을 얻었다. PG-4-7-1-2 분획 $(420 \mathrm{mg})$ 은 앞 분획과 동일한 컬 럼을 사용하였고 이동상의 기울기 조건은 A : B $(90: 10,0-0.15$ $\min ), \mathrm{A}: \mathrm{B}$ (80:20, 0.15-5 min), A : B (50:50, 5-30 min), A : B (40:60, 30-40 min)의 조건에서 $3 \mathrm{~mL} / \mathrm{min}$ 의 유속으로 $203 \mathrm{~nm}$ 파장에서 분리를 하였으며, 총 11 개의 분획물(PG-4-7-1-2-1-PG4-7-1-2-11)을 얻었다. PG-4-7-1-4 분획 $(520 \mathrm{mg})$ 은 앞 분획과 동일한 컬럼을 사용하였고 이동상의 기울기 조건은 A : B (80:20, $0-0.15 \mathrm{~min}), \mathrm{A}: \mathrm{B}(50: 50,40 \mathrm{~min}), \mathrm{A}: \mathrm{B} \quad(0: 100,45 \mathrm{~min})$ 의 조건에서 $2 \mathrm{~mL} / \mathrm{min}$ 의 유속으로 $203 \mathrm{~nm}$ 파장에서 분리를 하였 으며, 총 7개의 분획물(PG-4-7-1-4-1-PG-4-7-1-4-7)을 얻었다. 위에서 얻은 분획물 중 TLC로 확인 시 malonyl ginsenoside가 


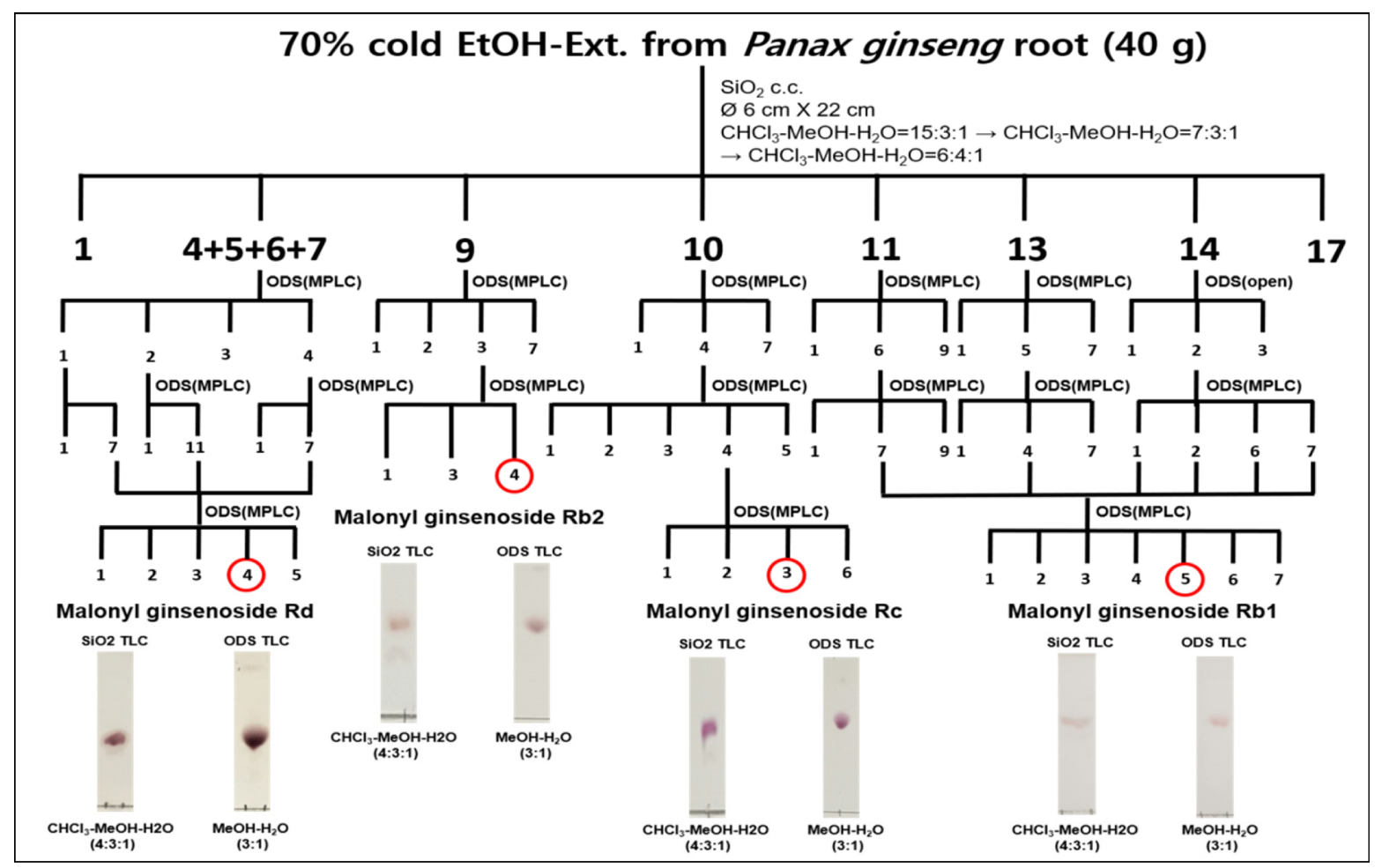

Fig. 1 Isolation procedure of malonyl ginsenoside from panax ginseng

존재할 것으로 예상되는 PG-4-7-1-7, PG-4-7-2-11, PG-4-7-47 분획(총 $85.7 \mathrm{mg}$ )을 합쳐서 앞 분획과 같은 MPLC조건으로 분 리를 진행한 결과 화합물 $1(26.6 \mathrm{mg})$ 를 분리하였다(Fig. 1). PG-9 $(287 \mathrm{mg})$ 에 대하여 분취컬럼 $(\Phi 10 \mathrm{~mm})$ 및 이동상의 기 울기는 $\mathrm{A}$ : B (90:10, 0-15 $\mathrm{min})$ 의 조건에서 $2 \mathrm{~mL} / \mathrm{min}$ 의 유속으 로 $203 \mathrm{~nm}$ 파장에서 분리를 하였고 총 7개의 분획물 $(\mathrm{PG}-9-1-$ PG-9-7)을 얻었다. PG-9-3 (40 mg)에 대하여 앞 분획과 동일한 컬럼을 사용하였으며 이동상의 기울기는 $\mathrm{A}: \mathrm{B}\left(\mathrm{H}_{2} \mathrm{O}: \mathrm{MeOH}\right.$, $28: 72,60 \mathrm{~min})$ 의 조건에서 $2.5 \mathrm{~mL} / \mathrm{min}$ 의 유속으로 $203 \mathrm{~nm}$ 파 장에서 분리를 하였으며 총 4 개의 분획물을 얻었고, 그중 화합 물 $3(13.5 \mathrm{mg})$ 를 분리하였다. PG-10 (267 mg)에 대하여 앞분 획과 동일한 컬럼을 사용하였으며 이동상의 기울기는 $\mathrm{A}: \mathrm{B}$ $\left(\mathrm{H}_{2} \mathrm{O}: \mathrm{MeOH}, 71: 29,0-50 \mathrm{~min}\right)$ 의 조건에서 $3 \mathrm{~mL} / \mathrm{min}$ 의 유속으 로 $203 \mathrm{~nm}$ 파장에서 분리를 하였으며 총 7 개의 분획물 $(\mathrm{PG}-10-$ 1-PG-10-7)을 얻었다. 그 중PG-10-4 분획(204 mg)에 대하여 앞 분획과 동일한 조건으로 $\mathrm{MPLC}$ 진행결과 총 5 개의 분획물을 얻 었으며, PG-10-4-4 분획 $(119.5 \mathrm{mg})$ 으로 이동상의 기울기를 $\mathrm{A}$ : B $\left(\mathrm{H}_{2} \mathrm{O}: \mathrm{MeOH}, 28: 72,0-60 \mathrm{~min}\right)$ 로 조절하여 $\mathrm{MPLC}$ 를 진행한 결과 화합물 2 (PG-10-4-4-3, $7 \mathrm{mg}$ )를 분리하였다. PG-11 분획 $(1 \mathrm{~g})$ 에 사용된 컬럼은 YMC-pack pro $\mathrm{C} 18(20 \mathrm{~mm} \times 250 \mathrm{~mm}$, $10 \mu \mathrm{m})$ 를 사용하였으며 이동상의 기울기는 $\mathrm{A}: \mathrm{B}(90: 10,0 \mathrm{~min})$, $\mathrm{A}: \mathrm{B}(0: 100,70 \mathrm{~min})$ 의 조건에서 $15 \mathrm{~mL} / \mathrm{min}$ 의 유속으로 210 $\mathrm{nm}$ 파장에서 분획을 진행하였으며, 총 9 개의 분획물(PG-11-1PG-11-9)을 얻었다. 그중 PG-11-6 분획 $(408 \mathrm{mg}$ )에 사용된 컬럼 은 YMC-pack pro $\mathrm{C} 18(10 \mathrm{~mm} \times 250 \mathrm{~mm}, 5 \mu \mathrm{m})$ 를 사용하였으 며 기울기는 A : B $(90: 10,0 \mathrm{~min}), \mathrm{A}: \mathrm{B}(0: 100,70 \mathrm{~min})$ 조건 에서 $2 \mathrm{~mL} / \mathrm{min}$ 의 유속으로 $210 \mathrm{~nm}$ 파장에서 분리를 진행한 결
과 총 9개의 분획물(PG-11-6-1-PG-11-6-9)을 얻었다. PG-13 분 획 $(1.3 \mathrm{~g})$ 에 대하여 앞 $\mathrm{PG}-11$ 분획과 동일한 조건으로 MPLC진 행결과 총 7개의 분획물(PG-13-1-PG-13-7)을 얻었다. PG-13-5 분획 $(408 \mathrm{mg})$ 에 대하여 앞 PG-11-6분획과 동일한 조건으로 MPLC진행결과 총 7개의 분획물(PG-13-5-1-PG-13-5-7)을 얻었 다. $\mathrm{PG}-14$ 분획 $(1.7 \mathrm{~g})$ 에 대하여 분취컬럼 $(\Phi 20 \mathrm{~mm})$ 및 이동상 의 기울기는 $\mathrm{A}: \mathrm{B}(78: 22,0 \mathrm{~min}), \mathrm{A}: \mathrm{B}(50: 50,30 \mathrm{~min})$ 의 조 건에서 $16 \mathrm{~mL} / \mathrm{min}$ 의 유속으로 $203 \mathrm{~nm}$ 파장에서 $\mathrm{MPLC}$ 를 진행 한결과 총 3개의 분획물(PG-14-1-PG-14-3)을 얻었다. PG-14-2 분획 $(875 \mathrm{mg})$ 분획에 대하여 분취컬럼 $(\Phi 20 \mathrm{~mm})$ 및 이동상의 기울기는 A : B $(65: 35,0-30 \mathrm{~min})$ 조건에서 $2 \mathrm{~mL} / \mathrm{min}$ 의 유속으 로 $203 \mathrm{~nm}$ 파장에서 분리를 하였으며, 총 7개의 분획물(PG-142-1-PG-14-2-7)을 얻었다. 위에서 얻어진 분획물 중 TLC로 확 인 시 malonyl ginsenoside가 존재할 것으로 예상되는 PG-116-7, PG-13-5-4, 및 PG14-2-1,2,6,7 분획(총 98.8 mg)을 합쳐서 다음 분획을 진행하였다. 분취컬럼 $(\Phi 10 \mathrm{~mm})$, 이동상의 기울기 [A : B (60:40, $0 \mathrm{~min}), \mathrm{A}: \mathrm{B}(50: 50,30 \mathrm{~min}), \mathrm{A}: \mathrm{B} \quad(0: 100$, $35 \mathrm{~min}), \mathrm{A}: \mathrm{B}(0: 100,40 \mathrm{~min})], 0.8 \mathrm{~mL} / \mathrm{min}$ 의 유속 및 203 $\mathrm{nm}$ 의 흡광도 값을 설정하고 $\mathrm{MPLC}$ 를 진행한 결과 화합물 4 [14 mg]을 얻었다(Fig. 1).

화합물 1 (Malonyl ginsenoside $\mathrm{Rd}$ ): White amorphous powder $(\mathrm{MeOH})$; m.p. $158-161^{\circ} \mathrm{C} ;[\alpha]_{\mathrm{D}}^{20}+16.4^{\mathrm{o}}$; IR $(\mathrm{KBr})$ $v_{\max } 3383,2937,1730,1600,1383,1074 \mathrm{~cm}^{-1}$; Negative ESI/MS $1031.54201 \quad[\mathrm{M}-\mathrm{H}]^{-}$; ${ }^{1} \mathrm{H}-\mathrm{NMR} \quad\left(600 \mathrm{MHz}, \mathrm{CD}_{3} \mathrm{OD}\right.$, $\left.\delta_{\mathrm{H}}\right)$ and ${ }^{13} \mathrm{C}-\mathrm{NMR}\left(150 \mathrm{MHz}, \mathrm{CD}_{3} \mathrm{OD}, \delta_{\mathrm{C}}\right)$ in Table 1.

화합물 2 (Malonyl ginsenoside Rc): White amorphous powder $(\mathrm{MeOH})$; m.p. $150-152^{\circ} \mathrm{C} ;[\alpha]_{\mathrm{D}}^{20}+1.7^{\circ}$; IR $(\mathrm{KBr}) v_{\max } 3381$, 
Table $1{ }^{1} \mathrm{H}-\mathrm{NMR}(600 \mathrm{MHz})$ and ${ }^{13} \mathrm{C}-\mathrm{NMR}(150 \mathrm{MHz})$ spectral data of compounds $\mathbf{1 - 4} \delta$ in ppm, $J$ in $\mathrm{Hz}$

\begin{tabular}{|c|c|c|c|c|c|c|c|c|}
\hline \multirow{2}{*}{ No. } & \multicolumn{2}{|r|}{ 1 $^{\text {a) }}$} & \multicolumn{2}{|r|}{$2^{\mathrm{b})}$} & \multicolumn{2}{|r|}{$3^{\text {b) }}$} & \multicolumn{2}{|r|}{$4^{\text {b) }}$} \\
\hline & $\delta_{\mathrm{C}}$ & $\delta_{\mathrm{H}}(J$ in $\mathrm{Hz})$ & $\delta_{\mathrm{C}}$ & $\delta_{\mathrm{H}}(J$ in $\mathrm{Hz})$ & $\delta_{\mathrm{C}}$ & $\delta_{\mathrm{H}}(J$ in $\mathrm{Hz})$ & $\delta_{\mathrm{C}}$ & $\delta_{\mathrm{H}}(J$ in $\mathrm{Hz})$ \\
\hline 1 & 39.53 & $0.71^{\#}, 1.49^{\#}$ & 39.51 & $0.70^{\#}, 1.50^{\#}$ & 39.53 & $0.71^{\#}, 1.52^{\#}$ & 39.54 & $0.73^{\#}, 1.51^{\#}$ \\
\hline 2 & 27.14 & $1.79^{\#}, 2.13^{\#}$ & 26.95 & $1.81^{\#}, 2.16^{\#}$ & 27.12 & $1.81^{\#}, 2.16^{\#}$ & 26.94 & $1.80^{\#}, 2.16^{\#}$ \\
\hline 3 & 89.62 & $3.23, \mathrm{dd}, 11.5,4.3$ & 89.55 & $3.22, \mathrm{dd}, 11.7,4.3$ & 89.58 & $3.23, \mathrm{dd}, 11.7,4.3$ & 89.59 & $3.24, \mathrm{dd}, 11.8,4.3$ \\
\hline 4 & 40.35 & - & 40.34 & - & 40.35 & - & 40.36 & - \\
\hline 5 & 56.81 & $0.66^{\#}$ & 56.79 & $0.65^{\#}$ & 56.80 & $0.66^{\#}$ & 56.81 & $0.67^{\#}$ \\
\hline 6 & 18.78 & $1.47^{\#}, 1.36^{\#}$ & 18.77 & $1.46^{\#}, 1.34^{\#}$ & 18.77 & $1.34^{\#}, 1.46^{\#}$ & 18.77 & $1.47^{\#}, 1.36^{\#}$ \\
\hline 7 & 35.46 & $1.14^{\#}, 1.43^{\#}$ & 35.45 & $1.14^{\#}, 1.43^{\#}$ & 35.46 & $1.20^{\#}, 1.45^{\#}$ & 35.47 & $1.13^{\#}, 1.45^{\#}$ \\
\hline 8 & 40.09 & - & 40.05 & - & 40.06 & - & 40.06 & - \\
\hline 9 & 50.52 & $1.34^{\#}$ & 50.51 & $1.33^{\#}$ & 50.53 & $1.32^{\#}$ & 50.55 & $1.33^{\#}$ \\
\hline 10 & 37.24 & - & 37.23 & - & 37.24 & - & 37.24 & - \\
\hline 11 & 31.23 & $1.52^{\#}, 1.94^{\#}$ & 31.10 & $1.48^{\#}, 1.95^{\#}$ & 31.01 & $1.52^{\#}, 1.95^{\#}$ & 31.13 & $1.53^{\#}, 1.96^{\#}$ \\
\hline 12 & 70.48 & $4.10^{\#}$ & 70.58 & $4.16^{\#}$ & 70.52 & $4.11^{\#}$ & 70.53 & $4.30^{\#}$ \\
\hline 13 & 49.82 & $1.94^{\#}$ & 49.75 & $1.95^{\#}$ & 49.79 & $1.94^{\#}$ & 49.86 & $1.97^{\#}$ \\
\hline 14 & 51.73 & - & 51.73 & - & 51.72 & - & 51.96 & - \\
\hline 15 & 31.06 & $0.97^{\#}, 1.53^{\#}$ & 31.02 & $0.96^{\#}, 1.34^{\#}$ & 31.09 & $0.96^{\#}, 1.52^{\#}$ & 31.03 & $0.96^{\#}, 1.53^{\#}$ \\
\hline 16 & 26.96 & $1.34^{\#}, 1.79^{\#}$ & 27.10 & $1.34^{\#}, 1.80^{\#}$ & 26.97 & $1.34^{\#}, 1.80^{\#}$ & 27.13 & $1.36^{\#}, 1.81^{\#}$ \\
\hline 17 & 51.94 & $2.52^{\#}$ & 51.98 & $2.52^{\#}$ & 51.99 & $2.54^{\#}$ & 51.71 & $2.56^{\#}$ \\
\hline 18 & 16.29 & $0.93, \mathrm{~s}$ & 16.31 & $0.92, \mathrm{~s}$ & 16.33 & $0.93, \mathrm{~s}$ & 16.34 & $0.94, \mathrm{~s}$ \\
\hline 19 & 16.63 & $0.79, \mathrm{~s}$ & 16.62 & $0.79, \mathrm{~s}$ & 16.62 & $0.79, \mathrm{~s}$ & 16.62 & $0.81, \mathrm{~s}$ \\
\hline 20 & 83.61 & - & 83.66 & - & 83.82 & - & 83.78 & - \\
\hline 21 & 22.68 & $1.59, \mathrm{~s}$ & 22.68 & $1.61, \mathrm{~s}$ & 22.65 & $1.59, \mathrm{~s}$ & 22.72 & $1.58, \mathrm{~s}$ \\
\hline 22 & 36.45 & $1.80^{\#}, 2.34^{\#}$ & 36.45 & $1.80^{\#}, 2.34^{\#}$ & 36.48 & $1.80^{\#}, 2.35^{\#}$ & 36.50 & $1.81^{\#}, 2.37^{\#}$ \\
\hline 23 & 23.52 & $2.22^{\#}, 2.46^{\#}$ & 23.49 & $2.34^{\#}, 2.53^{\#}$ & 23.53 & $2.35^{\#}, 2.54^{\#}$ & 23.54 & $2.37^{\#}, 2.55^{\#}$ \\
\hline 24 & 126.27 & $5.21, \mathrm{t}, 6.9$ & 126.34 & 5.28, t-like & 126.26 & 5.28, t-like & 126.28 & 5.29, t-like \\
\hline 25 & 131.19 & - & 131.32 & - & 131.40 & - & 131.36 & - \\
\hline 26 & 26.06 & $1.57, \mathrm{~s}$ & 26.11 & $1.61, \mathrm{~s}$ & 26.11 & $1.61, \mathrm{~s}$ & 26.12 & $1.63, \mathrm{~s}$ \\
\hline 27 & 18.07 & $1.59, \mathrm{~s}$ & 18.19 & $1.64, \mathrm{~s}$ & 18.20 & $1.63, \mathrm{~s}$ & 18.27 & $1.63, \mathrm{~s}$ \\
\hline 28 & 28.37 & $1.30, \mathrm{~s}$ & 28.38 & $1.31, \mathrm{~s}$ & 28.37 & $1.31, \mathrm{~s}$ & 28.37 & $1.32, \mathrm{~s}$ \\
\hline 29 & 16.84 & $1.11, \mathrm{~s}$ & 16.84 & $1.11, \mathrm{~s}$ & 16.84 & $1.12, \mathrm{~s}$ & 16.84 & $1.14, \mathrm{~s}$ \\
\hline 30 & 17.69 & $0.91, \mathrm{~s}$ & 17.69 & $0.92, \mathrm{~s}$ & 17.71 & $0.91, \mathrm{~s}$ & 17.73 & $0.92, \mathrm{~s}$ \\
\hline $1^{\prime}$ & 105.23 & $4.86, d, 7.6$ & 105.15 & $4.87, \mathrm{~d}, 7.6$ & 105.17 & $4.87, \mathrm{~d}, 7.6$ & 105.19 & $4.88, \mathrm{~d}, 7.3$ \\
\hline $2^{\prime}$ & 84.75 & $4.12^{\#}$ & 84.34 & $4.14^{\#}$ & 84.52 & $4.13^{\#}$ & 84.52 & $4.13^{\#}$ \\
\hline $3^{\prime}$ & 78.43 & $4.27^{\#}$ & 78.39 & $4.16^{\#}$ & 78.40 & $4.23^{\#}$ & 78.40 & $4.15^{\#}$ \\
\hline $4^{\prime}$ & 71.99 & $4.12^{\#}$ & 72.42 & $3.95^{\#}$ & 72.13 & $4.01^{\#}$ & 72.02 & $4.01^{\#}$ \\
\hline $5^{\prime}$ & 78.26 & $3.85^{\#}$ & 78.00 & $4.26^{\#}$ & 78.11 & $3.86^{\#}$ & 78.13 & $3.90^{\#}$ \\
\hline $6^{\prime}$ & 63.22 & $4.29^{\#}, 4.43^{\#}$ & 63.10 & $4.30^{\#}, 4.51^{\#}$ & 63.14 & $4.32^{\#}, 4.51^{\#}$ & 63.13 & $4.33^{\#}, 4.51^{\#}$ \\
\hline $1^{\prime \prime}$ & 106.57 & $5.27, \mathrm{~d}, 7.6$ & 106.33 & $5.27, \mathrm{~d}, 7.6$ & 106.43 & $5.27, \mathrm{~d}, 7.6$ & 106.44 & $5.28, \mathrm{~d}, 7.3$ \\
\hline $2^{\prime \prime}$ & 77.05 & $4.06^{\#}$ & 76.96 & $4.07^{\#}$ & 77.05 & $4.03^{\#}$ & 77.19 & $4.02^{\#}$ \\
\hline $3^{\prime \prime}$ & 79.63 & $4.15^{\#}$ & 79.54 & $4.16^{\#}$ & 79.51 & $4.13^{\#}$ & 79.56 & $4.15^{\#}$ \\
\hline $4^{\prime \prime}$ & 71.73 & $4.18^{\#}$ & 71.71 & $4.26^{\#}$ & 71.73 & $4.21^{\#}$ & 71.73 & $4.20^{\#}$ \\
\hline $5^{\prime \prime}$ & 75.72 & $3.98^{\#}$ & 75.66 & $4.00^{\#}$ & 75.69 & $4.02^{\#}$ & 75.69 & $4.03^{\#}$ \\
\hline $6^{\prime \prime}$ & 65.72 & $4.94^{\#}$ & 65.39 & $4.95^{\#}$ & 65.54 & $4.96^{\#}$ & 65.56 & $4.97^{\#}$ \\
\hline $1^{\prime \prime \prime}$ & 98.59 & $5.16, d, 7.7$ & 98.42 & $5.11, \mathrm{~d}, 7.7$ & 98.45 & $5.10, \mathrm{~d}, 7.7$ & 98.41 & $5.11, \mathrm{~d}, 7.8$ \\
\hline $2^{\prime \prime \prime}$ & 75.46 & $3.97^{\#}$ & 75.38 & $3.94^{\#}$ & 75.23 & $3.89^{\#}$ & 75.19 & $3.90^{\#}$ \\
\hline $3^{\prime \prime \prime}$ & 78.88 & $3.88^{\#}$ & 78.71 & $3.87^{\#}$ & 78.78 & $4.26^{\#}$ & 78.71 & $4.27^{\#}$ \\
\hline $4 " \prime \prime$ & 71.30 & $3.98^{\#}$ & 71.34 & $4.13^{\#}$ & 71.32 & $4.13^{\#}$ & 71.32 & $4.04^{\#}$ \\
\hline $5 " '$ & 78.62 & $3.88^{\#}$ & 76.86 & $4.09^{\#}$ & 77.00 & $3.98^{\#}$ & 75.69 & $4.09^{\#}$ \\
\hline $6^{\prime \prime \prime}$ & 63.16 & $4.44^{\#}, 4.51^{\#}$ & 68.80 & $4.00^{\#}, 4.63^{\#}$ & 69.53 & $4.21^{\#}, 4.65^{\#}$ & 65.56 & $4.19^{\#}, 4.70^{\#}$ \\
\hline $1^{\prime \prime \prime \prime}$ & - & - & 110.45 & $5.64, \mathrm{~d}, 1.4$ & 104.96 & $4.96, \mathrm{~d}, 5.9$ & 105.67 & $5.08, \mathrm{~d}, 7.7$ \\
\hline $2^{\prime \prime \prime \prime}$ & - & - & 83.73 & $4.84^{\#}$ & 72.46 & $4.42^{\#}$ & 75.57 & $4.03^{\#}$ \\
\hline $3 " ' "$ & - & - & 79.16 & $4.77^{\#}$ & 74.44 & $4.19^{\#}$ & 78.66 & $4.17^{\#}$ \\
\hline $4^{\prime \prime \prime \prime}$ & - & - & 86.33 & $4.72^{\#}$ & 68.90 & $4.34^{\#}$ & 71.90 & $4.26^{\#}$ \\
\hline $5^{\prime \prime \prime \prime}$ & - & - & 62.97 & $4.17^{\#}, 4.27^{\#}, 4.33^{\#}$ & 65.92 & $4.27^{\#}, 3.77^{\#}$ & 78.78 & $4.16^{\#}$ \\
\hline 6"'"' & - & - & - & - & - & - & 63.13 & $4.33^{\#}, 4.50^{\#}$ \\
\hline M1 & 169.06 & - & 169.65 & - & 169.23 & - & 169.72 & - \\
\hline M2 & 43.05 & $3.74, \mathrm{~s}$ & 43.49 & $3.75, \mathrm{~s}$ & 43.75 & $3.75, \mathrm{~s}$ & 44.62 & $3.76, \mathrm{~s}$ \\
\hline M3 & 170.30 & - & 171.28 & - & 170.72 & - & 171.40 & - \\
\hline
\end{tabular}

a) ${ }^{1} \mathrm{H}$ and ${ }^{13} \mathrm{C}$ NMR data was measured in $\mathrm{CD}_{3} \mathrm{OD} ;{ }^{\text {b) }} \mathrm{H}$ and ${ }^{13} \mathrm{C}$ NMR data was measured in pyridine- $d_{5}$; ${ }^{\#}$ overlapped 
2934, 1733, 1630, 1381, $1071 \mathrm{~cm}^{-1} ; \quad$ Negative ESI/MS $1163.46301 \quad[\mathrm{M}-\mathrm{H}]^{-} ; \quad{ }^{1} \mathrm{H}-\mathrm{NMR} \quad\left(600 \mathrm{MHz}\right.$, pyridine- $\left.d_{5}, \quad \delta_{\mathrm{H}}\right)$ and ${ }^{13} \mathrm{C}$-NMR $\left(150 \mathrm{MHz}\right.$, pyridine- $\left.d_{5}, \delta_{\mathrm{C}}\right)$ in Table 1 .

화합물 3 (Malonyl ginsenoside $\mathrm{Rb} 2$ ): White amorphous powder $(\mathrm{MeOH}) ;$ m.p. $148-150^{\circ} \mathrm{C} ; \quad[\alpha]_{\mathrm{D}}^{20}+11.5^{\circ}$; IR $(\mathrm{KBr})$ $v_{\max } 3384,2925,1731,1630,1378,1068 \mathrm{~cm}^{-1}$; Negative ESI/MS $m / z$ 1163.46301 [M-H] $]^{-}$; ${ }^{1} \mathrm{H}-\mathrm{NMR}(600 \mathrm{MHz}$, pyridine$\left.d_{5}, \delta_{\mathrm{H}}\right)$ and ${ }^{13} \mathrm{C}-\mathrm{NMR}\left(150 \mathrm{MHz}\right.$, pyridine- $\left.d_{5}, \delta_{\mathrm{C}}\right)$ in Table 1.

화합물 4 (Malonyl ginsenoside Rb1): White amorphous powder $(\mathrm{MeOH}) ; \quad$ m.p. $\quad 150-152^{\circ} \mathrm{C} ; \quad[\alpha]_{\mathrm{D}}^{20}+10.2^{\circ} ; \quad \mathrm{IR} \quad(\mathrm{KBr}) \quad v_{\max }$ 3421, 2918, 1729, 1597, 1380, $1071 \mathrm{~cm}^{-1}$; Negative ESI/MS $\mathrm{m} / \mathrm{z} 1194.59931 \quad[\mathrm{M}-\mathrm{H}]^{-}$; ${ }^{1} \mathrm{H}-\mathrm{NMR}\left(600 \mathrm{MHz}\right.$, pyridine- $\left.d_{5}, \delta_{\mathrm{H}}\right)$ and ${ }^{13} \mathrm{C}-\mathrm{NMR}\left(150 \mathrm{MHz}\right.$, pyridine- $\left.d_{5}, \delta_{\mathrm{C}}\right)$ in Table 1 .

\section{UPLC-ESI-Q-TOF/MS 분석}

분리된 화합물(1-4)을 $1 \mathrm{ppm}$ 의 농도로 희석하여 기기분석에 사 용하였다. UPLC가 부착된 Q-TOF/MS 장비 및 Thermo Hypersil Gold $(2.1 \mathrm{~mm} \times 100 \mathrm{~mm}, 1.9 \mu \mathrm{m})$ 를 사용하였고, 컬럼의 오븐 온 도는 $40{ }^{\circ} \mathrm{C}$ 로 설정하였다. 이동상 용매 시스템은 $0.1 \%$ formic $\mathrm{acid}$ 수용액 $(\mathrm{A})$ 와 $\mathrm{MeCN}(\mathrm{B})$ 로 이루어졌으며, 이동상 조건은 A : B (85:15, 0-0.5 min), A:B (80:20, 0.5-1 min), A : B (80:20, $1-6 \mathrm{~min}), \mathrm{A}: \mathrm{B}(70: 30,6-13 \mathrm{~min}), \mathrm{A}: \mathrm{B} \quad(65: 35,13-23 \mathrm{~min})$, A : B (62:38, 23-24 min), A : B (40:60, 24-27 min), A : B (10:90, 27-31 min), A : B (85:15, 31-32 min), 및 $\mathrm{A}: \mathrm{B}(85: 15$, 32-34 min)의 조건으로 진행 하였다. 컬럼 유속은 $0.5 \mathrm{~mL} / \mathrm{min}$ 이 며, 주입량은 $2 \mu \mathrm{L}$ 이었다. 분석에 사용된 기기의 주요 parameter 값은 선행문헌에서 ginsenoside 분석에 사용된 방법을 사용하였 다[13]. 장비 분석 및 데이터 수집에는 UNIFI software (Ver 1.8.1, Waters Corp.)를 사용하였다.

\section{UPLC-ESI-MS/MS 분석}

건조된 인삼의 동체를 조분쇄하여, 볼밀(Retsch MM400 mixer mill, Haan, Germany)을 이용하여 미세분말로 갈았다. $2 \mathrm{~mL}$ 튜 브에 인삼분말 $100 \mathrm{mg}$ 에 $80 \% \mathrm{MeOH}(1 \mathrm{~mL})$ 을 넣고 초음파 추출기(Bransonic 3510R-DTH, Branson Ultrasonics Co., Danbury, $\mathrm{CT}, \mathrm{USA}$ )를 이용하여 $40{ }^{\circ} \mathrm{C}$ 에서 30 분간 추출을 진행하였다. 원 심분리기(HITACHI koki Co. Ltd. Tokyo, Japan)를 이용하여 $13,500 \times \mathrm{g}$ 으로 5 분간 원심분리 하였다. 상등액 $(1 \mathrm{~mL})$ 을 취하여 감압 회전식 증발기(Eyela NVC-2100, Tokyo, Japan)를 이용하 여 용매를 제거하였다. 얻어진 추출물을 $\mathrm{MeOH}(1 \mathrm{~mL})$ 에 녹인 뒤, $0.2 \mu \mathrm{m}$ 필터(Chromdisc Co., Daegu, Korea)로 여과하여 기기분석에 사용하였다. 분리된 화합물의 정량분석을 위하여, UPLC가 부착된 3200 QTRAP LC/MS/MS system을 사용하였 으며, 컬럼은 ACQUITY BEH C18 $(2.1 \mathrm{~mm} \times 100 \mathrm{~mm}, 1.7 \mu \mathrm{m})$ 을 사용하였다. 컬럼의 오븐 온도는 $40{ }^{\circ} \mathrm{C}$ 로 설정하였으며 이동상 용매 시스템은 $0.1 \%$ formic acid 수용액 (A)와 $\mathrm{MeCN}$ (B)로 이루어졌으며 이동상은 위의 조건과 같은 조건으로 진행하였다. 컬럼 유속은 $0.5 \mathrm{~mL} / \mathrm{min}$ 이며, 주입량은 $5 \mu \mathrm{L}$ 이였다. 최적화된 질량분석은 Negative ion mode에서의 Multiple Reaction Monitoring (MRM mode)의 분석법을 이용하여 분리된 물질의 선구이온(precursor ion)을 선택 후, 선택된 선구이온에 대하여 충돌 에너지를 적용하고 생성이온(product ion)을 분석하여 정
량분석에 적용하였다. 분석 시에 사용된 기기의 중요 parameter 값 은 Table 2과 같다. 장비 분석 및 데이터 수집에는 BioAnalyst ${ }^{\mathrm{TM}}$ (Ver.1.4.2, AB SCIEX) 프로그램을 사용하였다.

\section{화합물의 정량}

분리된 화합물 4 종을 검량 곡선을 이용하여 정량 하였다. 각 물 질을 메탄올 수용액에 용해시켜 만들었으며 $-4{ }^{\circ} \mathrm{C}$ 에서 보관하 였다. 직선성은 $0.1-1 \mathrm{ppm}$ 사이의 4-5 농도에서 평가하였다.

\section{세포배양}

인간 간암 세포인 HepG2 (KCLB, Seoul, Korea) 세포는 $10 \%$ $(\mathrm{v} / \mathrm{v}) \mathrm{FBS}$ 를 첨가한 DMEM 배지 (Lonza, Basel, Switzerland) 와 $37,5 \% \mathrm{CO}_{2}, 95 \%$ humid air로 조절된 배양기를 사용하 여 배양하였다.

\section{세포 생존율 시험}

4종의 Malonyl ginsenoside의 세포독성 실험은 MTT colorimetric assay 방법을 이용하여 사용하였다[14]. HepG2 세포를 $5 \times 10^{4}$ cells $/ \mathrm{mL}$ 의 농도로 $100 \mu \mathrm{L}$ 씩 96 well plate에 분주하여 배양하 였다. 분주 12 시간 후에 인삼 화합물을 농도별로 처리하고 24 시간 후 $50 \mu \mathrm{L}$ 의 MTT [5 mg/mL in phosphate buffered saline] 시약을 첨가하여 다시 2시간 동안 배양하였다. 배양이 종료된 후, 배지를 제거하고 $100 \mu \mathrm{L}$ 의 $\mathrm{DMSO}$ 를 첨가하여 형성된 formazan을 용해하고 Microplate reader (Bio-Tek, Vermont,VT, USA)를 이용하여 $550 \mathrm{~nm}$ 에서 흡광도를 측정하였다. 분리된 화 합물들의 에탄올 독성 억제효과를 측정하기 위해 HepG2 세포 를 $5 \times 10^{4}$ cells $/ \mathrm{mL}$ 의 농도로 $100 \mu \mathrm{L}$ 씩 96 well plate에 분주하 고 12 시간 후에 $1 \mathrm{M}$ 의 에탄올과 화합물을 농도 별로 동시에 처 리하였다. 처리 24시간 후 위와 같은 방법으로 MTT assay를 수행하였다. 세포의 생존율은 다음과 같이 계산하였다.

Cell viability (\%)

$=[\mathrm{OD}($ compound $)-\mathrm{OD}($ Blank $) / \mathrm{OD}($ control) $-\mathrm{OD}($ Blank $)] \times 100$

\section{통계처리}

모든 실험 결과는 mean $\pm \mathrm{SD}$ 로 나타내었고 $(n=3)$, 각 실험군 간 차이의 통계적 유의성은 Graph-pad prism 5 software를 이용하 여 ANOVA 분산분석과 Tukey's multiple comparison test로 유의성 검정을 시행하였다 $(p<0.05)$.

\section{결과 및 고찰}

화합물 1은 White amorphous powder 형상으로서 TLC 전개 후, $10 \%$ 황산 발색 시 갈색으로 발색 되었다. 고분해능 질량분 석 장비를 이용하여 측정한 결과, $m / z 1031.5420[\mathrm{M}-\mathrm{H}]^{-}$peak 의 관측으로 질량 값은 $1032[\mathrm{M}]^{+}$로 확인하였다(Fig. 2). ${ }^{1} \mathrm{H}-$ $\mathrm{NMR}\left(600 \mathrm{MHz}, \mathrm{CD}_{3} \mathrm{OD}, \delta_{\mathrm{H}}\right)$ 스펙트럼에서 8 개의 methyl proton signal $\left(\delta_{\mathrm{H}} 1.59,1.59,1.57,1.30,1.11,0.93,0.91\right.$, 0.79)로부터(Table 1), 화합물 1의 aglycone이 dammarane 골격 임을 예상하였다. 또한 28 번 proton signal 이 $\delta_{\mathrm{H}} 1.30$ 에서 관 측되는 것으로, 이 화합물이 PPD-type인 것을 예상하였다[15]. 


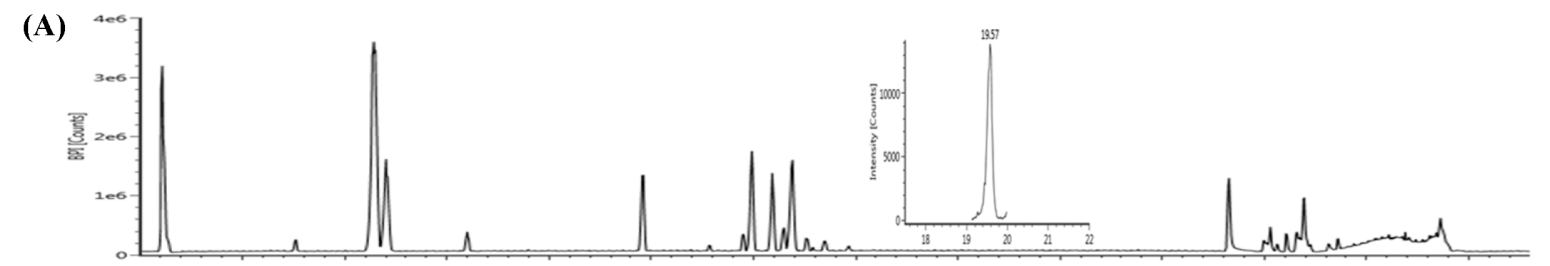

(B)
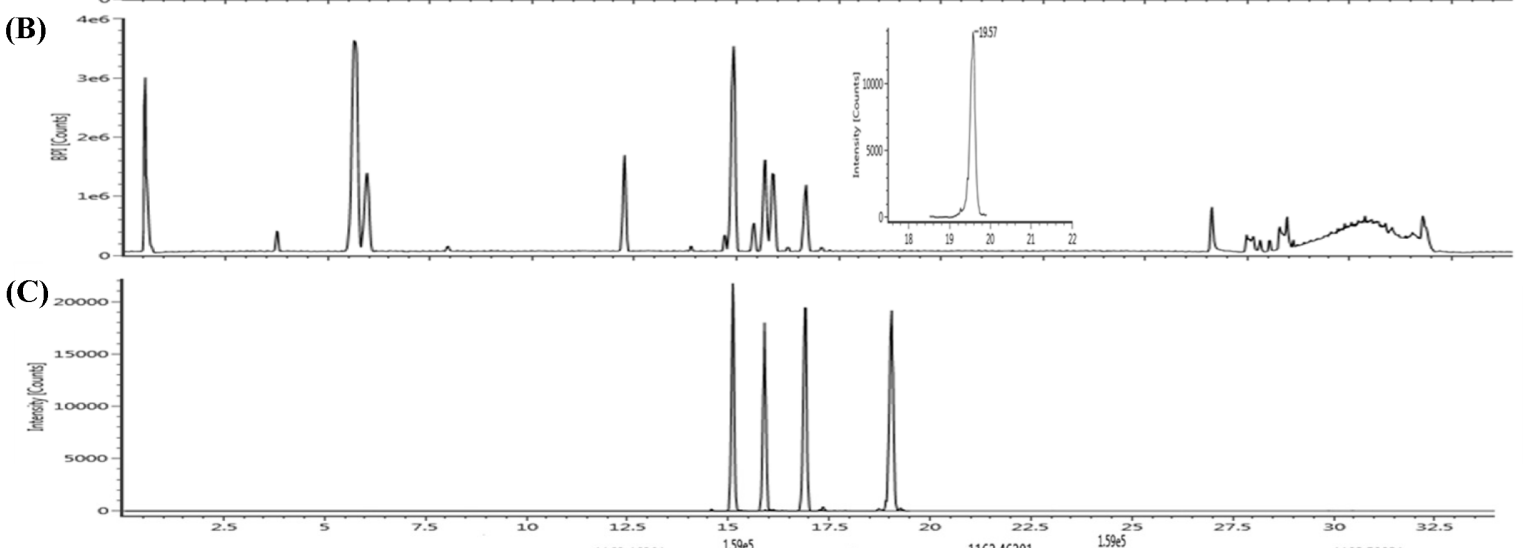

(D)

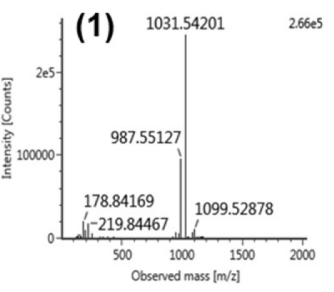

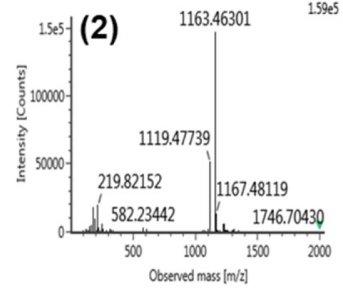
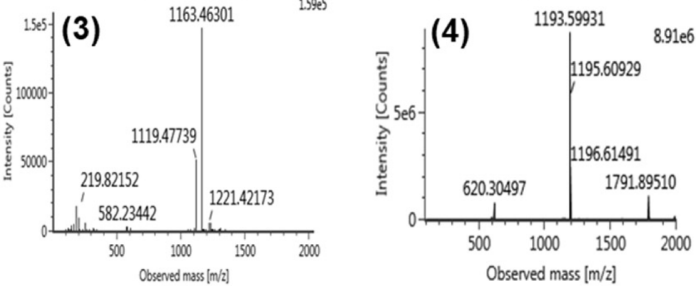

Fig. 2 Total ion chromatogram (TIC) of 6-years ginseng extract (A) and 5-years ginseng extract (B), and four malonyl ginsenosides (C) by UPLCQTOF/MS in negative-ion mode. (D) high resolution mass spectra of malonyl ginsenoside Rd (1) malonyl ginsenoside Rc (2) malonyl ginsenoside Rb2 (3), and malonyl ginsenoside Rb1 (4)

Table 2 Optimized MS/MS parameters of four malonyl ginsenosides

\begin{tabular}{ccccccc}
\hline \hline & $\mathrm{MRM}^{1)}$ & $\mathrm{Time}^{2)}$ & $\mathrm{DP}^{3)}$ & $\mathrm{EP}^{4)}$ & $\mathrm{CEP}^{5)}$ & -40 \\
M-Rd & $1031.358 / 987.5$ & 150 & -25 & -7.5 & -28 \\
M-Rc & $1163.348 / 1119.5$ & 150 & -50 & -9 & -44 & -36 \\
M-Rb2 & $1163.314 / 1119.4$ & 150 & -45 & -6.5 & -52 & -36 \\
M-Rb1 & $1193.333 / 1149.4$ & 150 & -60 & -7 & -56 & -38 \\
\hline
\end{tabular}

${ }^{1)}$ Multiple Reaction Monitoring, ${ }^{2)}$ Mass scan time, ${ }^{3)}$ Declustering Potential, ${ }^{4)}$ Entrance Potential, ${ }^{1)}$ Collision cell Entrance Potential, ${ }^{6}$ Collision Energy,

${ }^{7)}$ Collision cell Exit Potential

Olefin 영역에서 하나의 olefin methine proton signal $\left(\delta_{\mathrm{H}}\right.$ $5.21)$, 산소가 치환된 두 개의 methine proton signal $\left(\delta_{\mathrm{H}} 3.23\right.$, 4.10)을 관측하였다(Table 2). 세 개의 hemiacetal proton signal [ $\left.\delta_{\mathrm{H}} 5.27(\mathrm{H}-1 "), 5.16\left(\mathrm{H}-1^{\prime \prime \prime}\right), 4.86\left(\mathrm{H}-1^{\prime}\right)\right], 12$ 개의 oxygenated methine proton signal $\left[\delta_{\mathrm{H}} 4.27,4.18,4.15,4.12,4.12,4.06\right.$, $3.98,3.98,3.97,3.88,3.88,3.85]$, 그리고 세 개의 oxygenated methylene proton signal $\left[\delta_{\mathrm{H}} 4.94,4.51 / 4.44,4.43 / 4.29\right]$ 로부터 세 개의 당이 존재함을 예상하였다(Table 1). 이를 통해 이 화 합물이 PPD-type dammarane triterpene triglycoside임을 예상하 였다. 또한, 고자장 영역에서 하나의 methylene proton signal $\delta_{\mathrm{H}} 3.74(\mathrm{H}-\mathrm{M} 2)$ 을 관측하였다. ${ }^{13} \mathrm{C}-\mathrm{NMR}\left(150 \mathrm{MHz}, \mathrm{CD}_{3} \mathrm{OD}\right.$, $\delta_{\mathrm{C}}$ ) 스펙트럼에서 당으로부터 유래한 signal들을 제외한 탄소수 가 30 개임을 확인하였고, 이를 통해 triterpenoid임을 확인하였 다. 또한 당에서 유래한 세 개의 hemiacetal carbon signal [ $\delta \mathrm{c}$
106.56 (C-1"), 105.23 (C-1'), 98.59 (C-1"')], 12개의 oxygenated methine carbon signals $(\delta \mathrm{c} 84.75,79.63,78.88,78.62,78.43$, $78.26,77.05,75.72,75.46,71.99,71.73,71.30$ ), 세 개의 oxygenated methylene carbon signals ( $\delta \mathrm{c}$ 65.72, 63.22, 63.16)의 chemical shift 및 anomer proton signal의 결합 정수 $\left(J=7.6 \mathrm{~Hz}, \mathrm{H}-1\right.$ ', 1", $\left.J=7.7 \mathrm{~Hz}, \mathrm{H}-1^{\prime \prime \prime}\right)$ 로부터 세 당의 구조가 $\beta$-D-glucopyranose임을 확인하였다. Kim 등의 연구[24]에서 일 반적으로 $\beta$-D-glucopyranose의 C-2의 carbon signal은 대개 $74.7 \mathrm{ppm}$ 에서 관측되나, $\delta_{\mathrm{C}} 84.75$ 까지 저자장으로 이동한 것으 로 보아 $\beta$-D-glucopyranose가 다른 $\beta$-D-glucopyranose의 C-2의 수산기와 결합하여 glycosidation shift가 일어난 것임을 알 수 있었다. Peng 등의 연구[25]에서 C-20의 carbon signal은 대개 $72.9 \mathrm{ppm}$ 에서 관측되나, $\delta_{\mathrm{C}} 83.60$ 까지 저자장으로 이동한 것으 로 보아 $\beta$-D-glucopyranose가 C-20의 수산기와 결합하여 


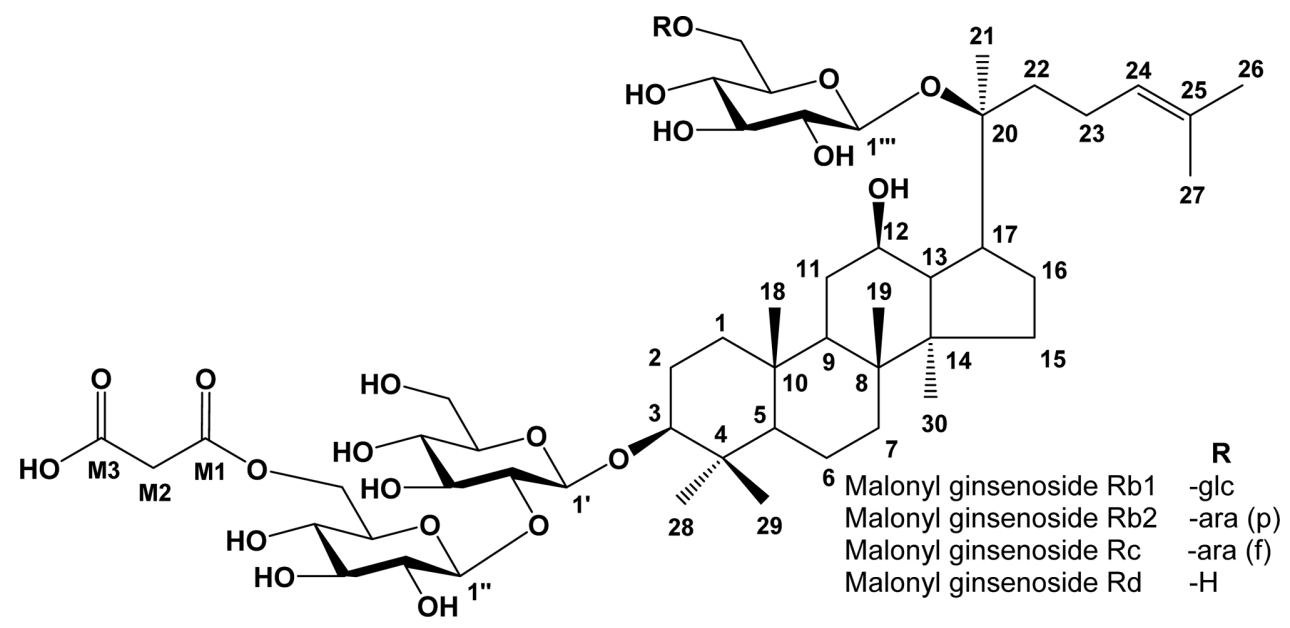

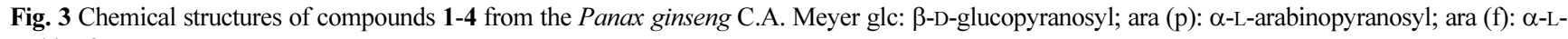
arabinofuranosy

glycosidation shift가 일어난 것임을 알 수 있었다(Table 1). 또 한 두 개의 carboxyl carbon signal [ $\delta_{\mathrm{C}} 170.30$ (C-M3), 169.06 (C-M1)]과 하나의 methylene carbon signal [ $\delta_{\mathrm{C}} 43.05$ (C$\mathrm{M} 2)$ ]를 관측하였으며, 이를 통해 malonyl 기가 하나 존재함을 예상하였다. 결합 위치를 확인하기 위하여 $\mathrm{gHMBC}$ 를 측정한 결과, 세 개의 anomer proton $\left(\delta_{\mathrm{H}} 5.27, \mathrm{H}-1 " ; 5.16, \mathrm{H}-1 "\right.$; $\left.4.86, \mathrm{H}-1^{\prime}\right)$ 이 각각 $\mathrm{C}-2^{\prime}$ 의 oxygenated methine carbon $(\delta \mathrm{c}$ 84.75), C-20의 oxygenated quaternary carbon ( $\delta \mathrm{c} 83.61), \mathrm{C}-3$ 의 oxygenated methine carbon ( $\delta \mathrm{c}$ 89.62)과 cross peak를 보 여 세 개의 $\beta$-D-glucopyranose가 각각 $2 ', 20,3$ 번에 결합하고 있음을 알 수 있었다. 또한 하나의 methylene proton signal $\left(\delta_{\mathrm{H}} 3.74, \mathrm{H}-\mathrm{M} 2\right)$ 이 두 개의 carboxyl carbon signal $\left(\delta_{\mathrm{C}} 171.40\right.$, 169.76)과 cross peak를 보여 malonyl 기가 존재함을 확인하였 고, 하나의 oxygenated methylene proton $\left(\delta_{\mathrm{H}} 4.94, \mathrm{H}-6^{\prime \prime}\right)$ 이 C-M1의 carboxyl carbon signal $\left(\delta_{\mathrm{C}}\right.$ 169.06)과 cross peak를 보여 malonyl 기가 $\beta$-D-glucopyranose의 C-6"에 결합해 있음을 확인하였다. 이를 종합해 문헌과 비교한 결과, malonyl ginsenoside Rd (Fig. 3)로 구조 동정하였다[18].

화합물 2는 White amorphous powder 형상으로서 TLC 전개 후, $10 \%$ 황산 발색 시 진한 갈색으로 발색 되었다. 고분해능 질량분석 장비를 이용하여 측정한 결과, $m / z 1163.4630$ [M-H] peak의 관측으로 질량 값은 $1164[\mathrm{M}]^{+}$로 확인하였다(Fig. 2). ${ }^{1} \mathrm{H}-\mathrm{NMR}\left(600 \mathrm{MHz}\right.$, pyridine- $\left.d_{5}, \delta_{\mathrm{H}}\right)$ spectrum 과 ${ }^{13} \mathrm{C}-\mathrm{NMR}$ $\left(150 \mathrm{MHz}\right.$, pyridine- $\left.d_{5}, \delta \mathrm{c}\right)$ spectrum을 통하여 화합물 $\mathbf{1}$ (malonyl ginsenoside Rd) 과 매우 유사한 구조에 당이 하나 더 결합했음을 예상하였다. 당에서 유래한 하나의 hemiacetal signal $\left(\delta_{\mathrm{C}} 110.45 ; \delta_{\mathrm{H}} 5.64\right)$, 세 개의 oxygenated methine signal $\left(\delta_{\mathrm{C}} 86.33,83.73,79.16 ; \delta_{\mathrm{H}} 4.72,4.84,4.77\right)$, 하나의 oxygenated methylene signal $\left(\delta_{\mathrm{C}} 63.10 ; \delta_{\mathrm{H}} 4.33 / 4.17\right)$ 의 chemical shift 및 anomer proton signal의 결합정수 $(J=1.4 \mathrm{~Hz})$ 로부터 당의 구조가 $\alpha$-L-arabinofuranose임을 확인하였다. 당의 결합 위치를 확인하기 위하여 $\mathrm{gHMBC}$ 를 확인한 결과, anomer proton $\left(\delta_{\mathrm{H}} 5.64, \mathrm{H}-1^{\prime \prime \prime}\right)$ 이 C-6"'의 oxygenated methylene carbon ( $\delta \mathrm{c}$ 68.93)과 cross peak를 보여 $\alpha$-L-arabinofuranose 가 $\beta$-D-glucopyranose의 6"'번에 결합하고 있음을 알 수 있었다
(Fig. 3). 이를 종합해서 문헌과 비교한 결과, malonyl ginsenoside Rc로 구조 동정하였다[18].

화합물 3는 White amorphous powder 형상으로서 TLC 전개 후, $10 \%$ 황산 발색 시 진한 갈색으로 발색 되었다. 고분해능 질량분석 장비를 이용하여 측정한 결과, $m / z 1163.4630[\mathrm{M}-\mathrm{H}]^{-}$ peak의 관측으로 질량 값은 $1164[\mathrm{M}]^{+}$로 확인하였다(Fig. 2). ${ }^{1} \mathrm{H}-\mathrm{NMR}\left(600 \mathrm{MHz}\right.$, pyridine- $\left.d_{5}, \delta_{\mathrm{H}}\right)$ spectrum 과 ${ }^{13} \mathrm{C}-\mathrm{NMR}$ $\left(150 \mathrm{MHz}\right.$, pyridine- $\left.d_{5}, \delta \mathrm{c}\right)$ spectrum을 통하여 역시 화합물 $\mathbf{1}$ (malonyl ginsenoside Rd)과 매우 유사한 구조에 당이 하나 더 결합했음을 예상하였다. 당에서 유래한 signal 들의 chemical shift 및 anomer proton signal의 결합정수 $(J=5.9 \mathrm{~Hz})$ 로부터 당의 구조가 $\alpha$-L-arabinopyranose임을 확인하였다. 당의 결합 위 치를 확인하기 위하여 $\mathrm{gHMBC}$ 를 확인한 결과, anomer proton $\left(\delta_{\mathrm{H}} 4.96, \mathrm{H}-1^{\prime \prime \prime}\right)$ 이 C-6"'의 oxygenated methylene carbon $(\delta \mathrm{c}$ 69.67)과 cross peak를 보여 $\alpha$-L-arabinopyranose 가 $\beta$-Dglucopyranose의 6"'번에 결합하고 있음을 알 수 있었다(Fig. 3). 이를 종합해서 문헌과 비교한 결과, malonyl ginsenoside $\mathrm{Rb} 2$ 로 구조 동정하였다[18].

화합물 4는 White amorphous powder 형상으로서 TLC 전개 후, $10 \%$ 황산 발색 시 진한 갈색으로 발색 되었다. 고분해능 질량분석 장비를 이용하여 측정한 결과, $m / z 1193.5993[\mathrm{M}-\mathrm{H}]^{-}$ peak의 관측으로 질량 값은 $1194[\mathrm{M}]^{+}$로 확인하였다(Fig. 2). ${ }^{1} \mathrm{H}-\mathrm{NMR} \quad\left(600 \mathrm{MHz}\right.$, pyridine- $\left.d_{5}, \delta_{\mathrm{H}}\right)$ spectrum 과 ${ }^{13} \mathrm{C}-\mathrm{NMR}$ $\left(150 \mathrm{MHz}\right.$, pyridine- $\left.d_{5}, \delta \mathrm{c}\right)$ spectrum을 통하여 역시 화합물 $\mathbf{1}$ (malonyl ginsenoside Rd)과 매우 유사한 구조에 당이 하나 더 결합했음을 예상하였다. 당에서 유래한 signal들의 chemical shift 및 anomer proton signal의 결합정수 $(J=7.7 \mathrm{~Hz})$ 로부터 당의 구 조가 $\beta$-D-glucopyranose임을 확인하였다. 당의 결합 위치를 확 인하기 위하여 $\mathrm{gHMBC}$ 를 확인한 결과, anomer proton $\left(\delta_{\mathrm{H}}\right.$ $\left.5.80, \mathrm{H}-1{ }^{\prime \prime \prime}\right)$ 이 C-6"'의 oxygenated methylene carbon ( $\delta \mathrm{c} 65.56$ ) 과 cross peak를 보여 $\beta$-D-glucopyranose가 다른 $\beta$-D-glucopyranose 의 6"'번에 결합하고 있음을 알 수 있었다(Fig. 3). 이를 종합해 서 문헌과 비교한 결과, malonyl ginsenoside Rb1로 구조 동정 하였다[19].

분리된 화합물 4종 및 인삼의 UPLC-Q-TOF/MS profiling 
Table 3 Identification of four malonyl ginsenosides in ginseng roots by UPLC-ESI-MS/MS

\begin{tabular}{|c|c|c|c|c|c|}
\hline Compounds & Identity & $\begin{array}{l}\text { Molecular } \\
\text { formula }\end{array}$ & M.W. & $\begin{array}{c}\text { measured value }^{1)} \\
{[\mathrm{M}-\mathrm{H}]^{-}}\end{array}$ & MS/MS fragmentations ${ }^{1)}$ \\
\hline 1 & M-Rd & $\mathrm{C}_{51} \mathrm{H}_{84} \mathrm{O}_{21}$ & 1032.548 & 1031.358 & 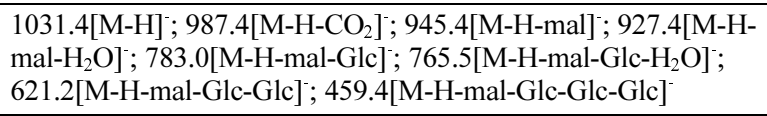 \\
\hline 2 & M-Rc & $\mathrm{C}_{56} \mathrm{H}_{92} \mathrm{O}_{25}$ & 1164.586 & 1163.348 & 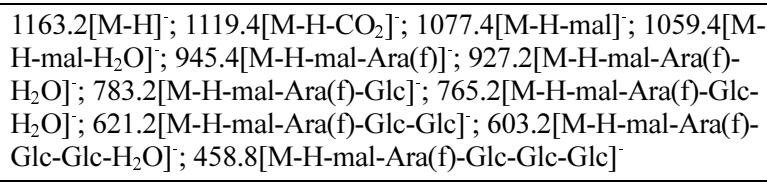 \\
\hline 3 & M-Rb2 & $\mathrm{C}_{56} \mathrm{H}_{92} \mathrm{O}_{25}$ & 1164.586 & 1163.314 & 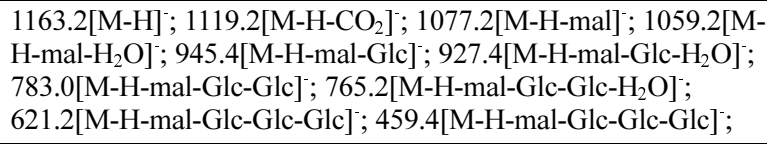 \\
\hline 4 & M-Rb1 & $\mathrm{C}_{57} \mathrm{H}_{94} \mathrm{O}_{26}$ & 1194.602 & 1193.333 & 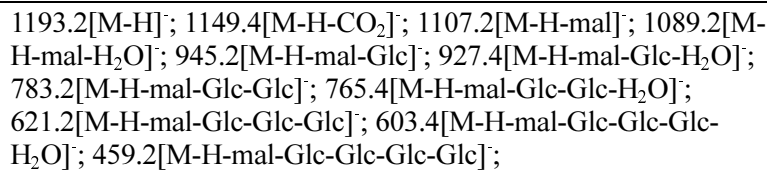 \\
\hline
\end{tabular}

${ }^{1)}$ mass accuracy $<5$ ppm

Table 4 Quantification of four malonyl ginsenosides

\begin{tabular}{ccccccc}
\hline \hline \multirow{2}{*}{ Compounds } & $\begin{array}{c}\text { Retention } \\
\text { Time (min) }\end{array}$ & Product Ion & Calibration Curve & $r^{2}$ & \multicolumn{2}{c}{$\begin{array}{c}\text { Linear } \\
\text { Range (ppm) }\end{array}$} \\
\cline { 5 - 7 } M-Rd & 9.40 & 987.5 & $y=26.1 x+867$ & 0.9956 & $0.1-1$ & 0.19 \\
M-Rc & 8.61 & 1119.5 & $y=7.76 x+9.77$ & 0.9988 & $0.1-1$ & 0.11 \\
M-Rb2 & 9.08 & 1119.4 & $y=5.63 x+791$ & 0.9957 & $0.1-1$ & 0.1 \\
M-Rb1 & 8.02 & 1149.4 & $y=11.5 x+578$ & 0.9976 & $0.1-1$ & 5.44 \\
\hline
\end{tabular}

결과를 활용하여(Fig. 2) 정량분석을 실시하였다. 미량의 정량분 석을 검출하기 위하여 UPLC가 부착된 QTRAP mass spectrometer $(\mathrm{AB} \mathrm{SCIEX)}$ 를 사용하여 질량 스펙트럼과 크로마토그램을 분석 하였다. 최적화된 기기분석조건을 고려하여 머무름 시간을 비교 하였을 때, 화합물 1은 9.40분, 화합물 2은 8.61분, 화합물 3은 9.08 분, 화합물 4 는 7.73 분에서 검출되었다(Table 3). MRMmode로 정량 분석을 실시하기 위하여 선택된 선구이온(precursor ion)은 화합물 1은 $\mathrm{m} / \mathrm{z} \mathrm{1033}$, 화합물 2는 $\mathrm{m} / \mathrm{z} 1163$, 화합물 3 는 $m / z 1163$, 화합물 4는 $m / z \quad 1193$ 로 선택되었다. 최적의 fragment 에너지를 형성하였고 조각난 질량 값 중에 가장 감도 가 좋은 생성이온(products ion)을 선택하여(화합물 1: m/z

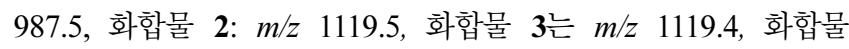
4는 $\mathrm{m} / z$ 1149.4) 정량분석을 실시하였다(Table 3). 검량 곡선은 표준물질의 5 농도 범위 안에서 측정된 값을 회귀 분석을 통해 작성하였다. 분석된 각 화합물의 상관계수 $\left(r^{2}\right)$ 는 0.9956 에서 0.9988으로서 매우 높은 값을 보여주었다(Table 4). 인삼에 함 유 되어있는 malonyl ginsenoside의 함량 분석을 진행하기 위하 여 수확 후, 바로 동결건조를 시킨 인삼 5년근 및 6년근을 세 근을 제거하고 동체만을 분석하였다. 그 결과 malonyl ginsenoside $\mathrm{Rb} 2$ 를 제외한 3종의 malonyl ginsenoside는 6년근 에 비해서 5 년근의 함량이 높게 나오는 것을 확인하였으며, 화 합물들의 총 함량의 합은 각각 6.62 및 $2.34 \mathrm{mg} / \mathrm{g}$ 으로 5 년근이 약 2.8 배 높은 것을 확인하였다(Table 4). Wan 등의 연구에서 도 5 년근보다 6 년근에서 malonyl ginsenoside의 함량이 적은 것
이 보고가 되어 있어 본 연구와 비슷한 결과라고 할 수 있겠다 [20].

한편, 분리된 malonyl ginsenoside 4종의 간세포에 대한 독성 을 평가하기 위해 MTT assay를 수행한 결과, 화합물 모두 HepG2 $(100 \mu \mathrm{M})$ 세포에 대한 독성을 나타내지 않는 것을 확 인하였다(Fig. 4B). 세포손상을 유발하기 위하여 알코올 $(1 \mathrm{M})$ 를 처리하여 독성 유발에 따른 세포의 손상 또는 세포 사멸에 대 한 화합물의 간세포 보호효과를 확인하기 위해 알코올 처리에 따른 세포 생존율의 변화를 확인한 결과, 알코올 처리군은 정 상 대조군 $(100 \%)$ 과 비교하여 세포 생존율이 약 $48.6 \%$ 까지 감 소하였다. 알코올 처리 후 Malonyl ginsenoside $\mathrm{Rd}$ 의 처리군은 $71.3 \%$ 의 세포 생존율을 나타났었고, 알코올 처리군과 비교 시 $41.4 \%(50 \mu \mathrm{M})$ 의 세포가 회복되었으며, 나머지 화합물은 활성 이 없었다(Fig. 4A). Malonyl ginsenoside Rd는 항당뇨 효과가 보고되어 있으며[21], 손상된 간세포 회복 개선 효과에는 본 논 문에서 처음 보고하였다.

본 연구 결과를 종합해 볼 때, 분리가 어렵고 분해가 되기 쉬운 주요 malonyl ginsenoside의 수율을 최대화하기 위하여 10 ${ }^{\circ} \mathrm{C}$ 이하에서 추출 및 저온 감압 농축하였다. 4종의 malonyl ginsenoside의 분리 및 동정 된 자료의 최신 NMR data 값 및 고분해능 질량 값을 제공하였으며, 인삼의 연근별 주요 ginsenoside의 변화 및 가공 시 변화가 될 수 있는 ginsenoside 의 제안을 위한 기초자료로 이용할 수 있을 것으로 기대된다. 

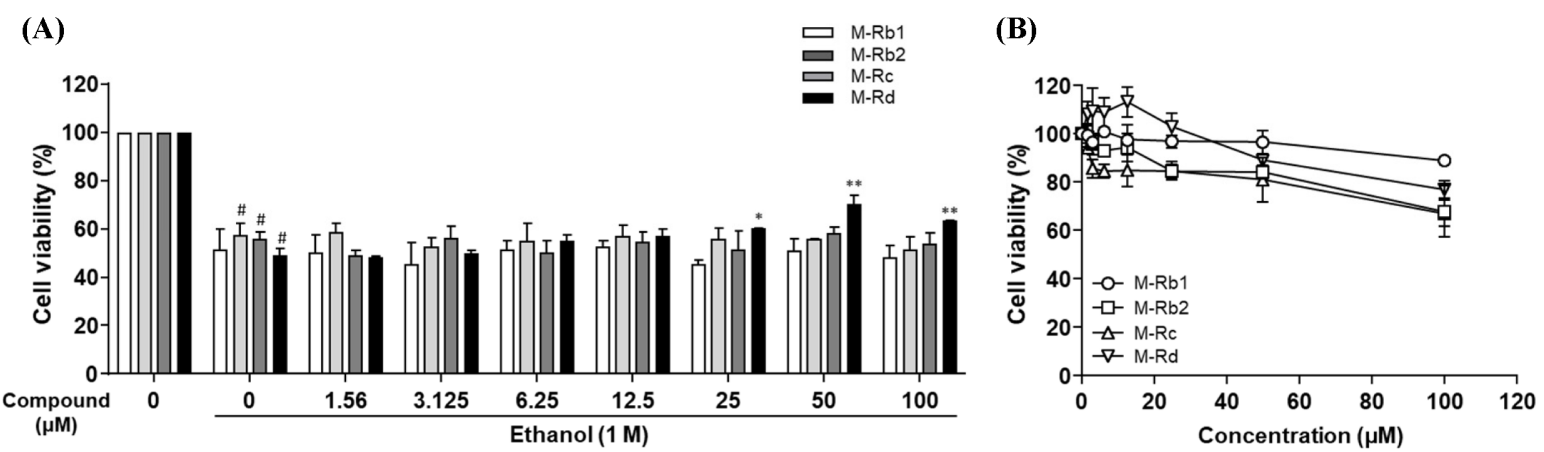

Fig. 4 Effect of malonyl ginsenosides on the cytotoxicity in ethanol-damaged HepG2 cells. (A) HepG2 cells were treated with $1 \mathrm{M}$ ethanol and various concentrations of malonyl ginsenosides for $24 \mathrm{~h}$. (B) HepG2 cells were treated with various concentrations of malonyl ginsenosides for $24 \mathrm{~h}$. Cell viability was measured using a MTT assay. Values are expressed as the mean $\pm \mathrm{SD} .{ }^{*} p<0.001$; control $v s$. ethanol only treated HepG2 cells, ${ }^{*} p<0.05$ and ${ }^{*} p<0.01$; ethanol only treated HepG2 cells $v s$. ethanol and malonyl ginsenosides-treated HepG2 cells

\section{초 록}

고려인삼(Panax ginseng C.A. Meyer)을 $70 \% \mathrm{EtOH}$ 수용액으 로 저온 추출한 뒤, 감압 농축한 추출물을 $\mathrm{SiO}_{2}, \mathrm{ODS}$ column chromatograph 및 중압분취(MPLC) 장비를 반복 실시하여 4종 의 인삼 사포닌 화합물을 분리 및 정제하였다. NMR 및 고분 해능 질량분석 장비를 이용하여 malonyl ginsenoside $\mathrm{Rd}$ (1), $\mathrm{Rc}$ (2), $\mathrm{Rb} 2$ (3), 및 $\mathrm{Rb} 1$ (4)로 구조 동정하였다. 분리한 4종의 화합물에 대하여 UPLC-MS/MS 질량분석기를 이용하여 수삼의 5년 및 6년근 뿌리의 동체를 정량분석 하였으며, malonyl ginsenoside의 총 함량의 합은 각각 6.62 및 $2.34 \mathrm{mg} / \mathrm{g}$ 으로 5 년 근이 약 2.8 배 높은 것을 확인하였다. 인삼으로부터 분리된 화 합물 중 malonyl ginsenoside $\mathrm{Rd}$ 의 경우, 알코올에 의해 저해 된 $\mathrm{HepG} 2$ 세포에 대해서 간세포를 보호하는 효과가 있음을 확 인하였다.

Keywords 인삼 · 정량분석 · HepG2 - Malonyl ginsenoside · Nuclear magnetic resonance

감사의 글 본 논문은 농촌진흥청 공동연구사업(과제번호: PJ01420403)의 지원에 의해 이루어진 것으로 이에 감사드립니다.

\section{References}

1. Gillis CN (1997) Panax ginseng pharmacology: A nitric oxide link. Biochem Pharmacol 54(1): 1-8

2. Yun TK (2001) Brief introduction of Panax ginseng C.A. Meyer. J Korean Med Sci 16: S3-S5

3. Park JD, Rhee DK, Lee YH (2005) Biological activites and chemistry of saponins from Panax ginseng C. A. Meyer. Phytochem Rev 4: 159-175

4. Lee JW, Ji SH, Choi BR, Choi DJ, Lee YG, Kim HG, Kim GS, Kim KI, Lee YH, Baek NI, Lee DY (2018) UPLC-QTOF/MS-based metabolomics applied for the quality evaluation of four processed Panax ginseng products. Molecules 23: 2062

5. Kitagawa I, Taniyama T, Yoshikawa M, Ikenishi Y, Nakagawa Y (1989) Chemical studies on crude drug processing. VI.: Chemical structures of malonyl-ginsenoside $\mathrm{Rb}_{1}, \mathrm{Rb}_{2}, \mathrm{Rc}$, and $\mathrm{Rd}$ isolated from root of Panax ginseng C. A. Meyer. Chem Pharm Bull 37: 2961-2970
6. Shin JY, Choi EH, Wee JJ (2001) The difference of ginsenoside compositions according to the conditions of extraction and fractionation of crude ginseng saponins. Environ Toxicol Pharmacol 33: 282-287

7. Kitagawa I, Taniyama T, Hayashi T, Yoshikawa M (1983) Malonylginsenosides $\mathrm{Rb}_{1}, \mathrm{Rb}_{2}$, Rc, and $\mathrm{Rd}$, four new malonylated dammaranetype triterpene oligoglycosides from Ginseng Radix. Chem Pharm Bull 31(9): 3353-3356

8. Qiu S, Yang WZ, Yao CL, Shi XJ, Li JY, Lou Y, Duan YN, Wu WY, Guo DA (2017) Malonylginsenosides with potential antidiabetic activities from the flower buds of Panax ginseng. J Nat Prod 80(4): 899908

9. Liu Z, Li W, Li X, Zhang M, Chen L, Zheng YN, Sun GZ, Ruan CC (2013) Antidiabetic effects of malonylginsenosides from Panax ginseng on type 2 diabetic rats induced by high-fat diet and streptozotocin. J Ethnopharmacol 145: 233-240

10. Liu Z, Li Y, Li X, Ruan CC, Wang LJ, Sun GZ (2012) The effects of dynamic changes of malonyl ginsenoside on evaluation and quality control of Panax ginseng C.A. Meyer. J Pharm Biomed Anal 64-65: 5663

11. Wu W, Sun L, Zhang Z, Guo Y, Liu S (2015) Profiling and multivariate statistical analysis of Panax ginseng based on ultra-high-performance liquid chromatography coupled with quadrupole-time-of-flight mass spectrometry. J Pharm Biomed Anal 107: 141-150

12. Nam KY, Hwang GB, Lee DY, Han JS, Noh HJ, Kim DH, Kim GS (2018) Variation in content of marker compounds and quality of processed white ginseng of different cultivation ages from different regions. Korean J Medicinal Crop Sci 26(5): 408-416

13. Yoon DH, Choi BR, Ma SH, Lee JW, Jo IH, Lee YS, Kim GS, Kim SM, Lee DY (2019) Metabolomics for age discrimination of ginseng using a multiplex approach to HR-MAS NMR spectroscopy, UPLC-QTOF/MS, and GC X GC-TOF/MS. Molecules 24(13): 2381

14. Philip S, Ritsa S, Dominic S, Anne M, James M, David V, Jonathan T, Heidi B, Susan K, Michael R (1990) New colorimetric cytotoxicity assay for anticancer-drug screening. J Nat Cancer Inst 82(13): 1107-1112

15. Shen R, Laval S, Cao X, Yu B (2018) Synthesis of $\Delta^{20}$-ginsenosides $\mathrm{Rh}_{4}$, $(20 E)-\mathrm{Rh}_{3}, \mathrm{Rg}_{6}$, and $\mathrm{Rk}_{1}$ : a general approach to access dehydrated ginsenosides. J Org Chem 83(5): 2601-2610

16. Kim HG, Oh HJ, Ko JH, Song HS, Lee YG, Kang SC, Lee DY, Baek NI (2019) Lanceoleins A-G, hydroxychalcones, from the flowers of Coreopsis lanceolata and their chemopreventive effects against human colon cancer cells. Bioorg Chem 85: 274-281

17. Peng M, Yi YX, Zhang D, Ding Y, Le J (2018) Stereoisomers of saponins in Panax notoginseng (Sanqi): a review front. Pharmacol 9(188): 1-18

18. Sun GZ, Liu Z, Li XG, Zheng YN, Wang JY (2005) Isolation and 
identification of two malonylginsenosides from the fresh root of Panax ginseng. Chin J Anal Chem 33: 1783-1786

19. Ruan CC, Liu Z, Li X, Liu X, Wang LJ, Pan HY, Zheng YN, Sun GZ, Zhang YS, Zhang LX (2010) Isolation and characterization of a new ginsenoside from the fresh root of Panax ginseng. Molecules 15: 23192325

20. Wan JY, Fan Y, Yu QT, Ge YZ, Yan CP, Raphael N, Li P, Ma ZH, Qi
LW (2015) Inergrated evaluation of malonyl ginsenosides, amino acids and polysaccharides in fresh and processed ginseng. J Pharm Biomed Anal 107: 89-97

21. Liu Z, Wang LJ, Li X, Hu JN, Chen Y, Ruan CC, Sun GZ (2009) Hypoglycemic effects of malonyl-ginsenosides extracted from roots of Panax ginseng on Streptozotocin-induced diabetic mice. J Phytother 23: 1426-1430 